Psihologijske teme, 27 (2018), 3, 339-363

Izvorni znanstveni rad - UDK - 613.25

316.64

159.922.2.072-057.875

doi:https://doi.org/10.31820/pt.27.3.1

\title{
Ispitivanje eksplicitnog i implicitnog stava prema pretilima kod studenata pomagačkih struka
}

\author{
Iva Kuculo \\ Poliklinika za zaštitu djece i mladih Grada Zagreba, Hrvatska \\ Etelka Kožar \\ SELECTIO Kadrovi, Zagreb, Hrvatska \\ Ajana Löw \\ Sveučilište u Zagrebu, Edukacijsko-rehabilitacijski fakultet, Zagreb, Hrvatska
}

\begin{abstract}
Sažetak
Cilj je istraživanja bio ispitati eksplicitni i implicitni stav prema pretilim osobama kod studenata nekih pomagačkih struka u Hrvatskoj. U istraživanju je sudjelovalo 429 sudionika, studenata psihologije i socijalnog rada Sveučilišta u Zagrebu. Stav je ispitan eksperimentalnom manipulacijom fotografije osobe kojoj je varirana težina (implicitna mjera) i upitnikom (eksplicitna mjera). Negativan je stav prema pretilima utvrđen i na implicitnoj i na eksplicitnoj mjeri. Dobivena je značajna razlika u procjenama radne uspješnosti i u procjenama triju dimenzija ličnosti osobe $s$ obzirom na tjelesnu težinu na fotografiji. U odnosu na osobu prosječne težine sudionici su pretilu osobu procjenjivali manje radno učinkovitom, emocionalno nestabilnijom, manje ekstravertiranom i manje otvorenom prema iskustvima. Iako su studenti psihologije, u odnosu na studente socijalnog rada, "strože" procjenjivali obje osobe, interakcija tjelesne težine na fotografiji i vrste studija procjenjivača nije utvrđena. Sudionici su u prosjeku iskazali i umjerenu razinu eksplicitnoga negativnog stava prema pretilima. Utvrđena je i povezanost negativnog stava s desničarskom autoritarnosti. Implicitne su mjere bile značajno, ali nisko povezane s eksplicitnom, što upućuje da postoji "prikriveni" dio stava koji zahvaća samo implicitna mjera. Dobiveni rezultati daju uvid u nedovoljno istražene spoznaje o stavu prema pretilima kod pomagačkih struka u Hrvatskoj te mogu biti korisne smjernice za programe smanjenja negativnog stava.
\end{abstract}

Ključne riječi: stav prema pretilim osobama, implicitna mjera stava, eksplicitna mjera stava, pomagačke struke

Ajana Löw, Edukacijsko-rehabilitacijski fakultet, Sveučilište u Zagrebu, Borongajska 83f, 10000 Zagreb, Hrvatska. E-pošta: ajana.low@erf.hr 


\section{Uvod}

Istraživanja pokazuju da je u zadnjih dvadeset godina razina diskriminacije pretilih osoba narasla za $66 \%$ te prelazi razinu diskriminacije drugih stigmatiziranih grupa (npr. Andreyeva, Puhl i Brownel, 2008; Latner, O'Brien, Durso, Brinkman i MacDonald, 2008; O'Brien, Latner, Ebneter i Hunter, 2013). Diskriminacija pretilih često započinje već u djetinjstvu, pa tako pretila djeca imaju veću mogućnost postati žrtvom vršnjačkog nasilja od djece prosječne težine (Janssen, Craig, Boyce i Pickett, 2004), što može ostaviti teške i dugoročne posljedice na mentalno zdravlje. Adolescenti koje vršnjaci ismijavaju zbog težine češće piju tablete za mršavljenje, laksative, nekontrolirano jedu (engl. binge eating), depresivniji su, imaju suicidalne misli, a svi su ti efekti jači kod djevojčica nego kod dječaka (Eisenberg, NeumarkSztainer, Haines i Wall, 2006; Haines, Neumark-Sztainer, Eisenberg, i Hannan, 2006). U odrasloj dobi pretile osobe, uz zdravstvene probleme, nerijetko imaju ozbiljne emocionalne i socijalne teškoće, kao što su depresija, problemi u ponašanju i smanjenje životnih prilika u bliskim odnosima te pri zapošljavanju (Berk, 2005; Robinson, Sutin i Daly, 2017; Sutin i Terracciano, 2017).

\section{Priroda negativnih stavova prema pretilima}

Kada govorimo o stavovima prema pretilim osobama, potrebno je razlikovati tri opće sastavnice (negativnih) međugrupnih stavova: (1) predrasude, koje obuhvaćaju vrstu emocije povezanu sa stavom i ekstremnost stava; (2) stereotipe, koji uključuju vjerovanja i misli koje čine stav te (3) diskriminaciju, koja se odnosi na ponašanje prema objektu stava. $\mathrm{S}$ obzirom na to da istraživanja najčešće ispituju samo jednu od sastavnica međugrupnog stava, u daljnjem ćemo pregledu literature navesti na koju se specifičnu sastavnicu stava istraživanje odnosilo.

Nelson (2009) navodi nekoliko ključnih razlika između negativnih stavova prema pretilima i ostalih negativnih međugrupnih stavova. Kao prvo, negativni su stavovi prema pretilima puno manje inhibirani socijalnom poželjnosti. Dok se o etničkim i rodnim međugrupnim stavovima često govori u javnosti te je raširena svijest da se treba raditi na njihovu smanjivanju, to ne vrijedi u slučaju stavova prema pretilima (McHugh i Kasardo, 2012). Postoji i zabrinjavajuće vjerovanje da diskriminacija, te sram i poniženje koje iz nje proizlaze, zapravo potiče pretile osobe da smršave (Brownell, Puhl, Schwartz i Rudd, 2005). Rezultati istraživanja opovrgavaju to vjerovanje; diskriminacija utemeljena na težini često dovodi do još većeg povećanja težine kod pretilih osoba (Hunger, Major, Blodorn i Miller, 2015), te do povećane smrtnosti (Sutin, Stephan i Terracciano, 2015). Također, za razliku od ostalih žrtava diskriminacije, kojima je osigurana određena razina zakonske zaštite, žrtve se ove vrste diskriminacije obično nemaju kome obratiti za pomoć (Puhl, Andreyeva i Brownell, 2008). 
Druga je bitna razlika što se pretile osobe smatraju odgovornima za svoju prekomjernu tjelesnu težinu (Tiggemann i Rothblum, 1997). Vjerovanje u pravedan svijet - vjerovanje da ljudi u životu "dobiju što su zaslužili" - potiče okrivljavanje pretilih ljudi za svoje stanje i povećava stigmatizaciju (Crandall, 1994). Fenomen ima adaptivnu funkciju jer omogućava ljudima da svoju socijalnu okolinu percipiraju kao stabilno mjesto koje funkcionira po određenim pravilima. Premda znatan utjecaj na težinu zapravo imaju biološki faktori, na pretilost se gleda kao na zanemarivanje osobne odgovornosti da se bude vitak (pri čemu se vitkost često neopravdano izjednačava sa zdravljem). Također, za razliku od drugih žrtava predrasuda koje se također smatraju krivima za svoje stanje, kao što su primjerice alkoholičari, pretilost je jasno vidljiva i brže uočljiva (Finkelstein, Frautschy Demuth i Sweeney, 2007).

Premda dosad ne postoji sustavno razrađena i empirijski provjerena teorija stavova prema pretilima, u svrhu boljeg razumijevanja može poslužiti nekoliko širih teorijskih pristupa u području međugrupnih stavova. Teorija sadržaja stereotipa (Fiske, Cuddy, Glick i Xu, 2002) pretpostavlja da sadržaj stereotipa uključuje dvije dimenzije - toplinu (stupanj u kojem se osoba procjenjuje društvenom) i kompetenciju (stupanj u kojem se osoba procjenjuje sposobnom). Kako se pretilost smatra preprekom za socijalne odnose te kontrolabilnom osobinom, pretilu se osobu vjerojatno procjenjuje nisko i na dimenziji topline (nema zadovoljavajuće socijalne odnose) i na dimenziji kompetencije (nedostatak samokontrole). Teorija međugrupnih emocija (Mackie, Devos i Smith, 2000) pretpostavlja da su međugrupni stavovi u velikoj mjeri određeni emocionalnim reakcijama. Kako mršavost ima viši društveni status od pretilosti, pretile se osobe mogu percipirati pripadnicima grupe niskog statusa te izazvati specifične emocije (npr. ljutnju ili gađenje), koje dovode do negativnog stava. Evolucijski pristupi (Neuberg, Smith i Asher, 2000) naglašavaju kako negativni međugrupni stavovi imaju adaptivnu važnost smanjivanja prijetnje. Pretili ljudi mogli bi predstavljati prijetnju jer ih se vezuje uz fizičku bolest (nasuprot fizičkom zdravlju). Teorija opravdavanja sustava (Jost i Banaji, 1994) pretpostavlja da su i grupe visokog i grupe niskog statusa motivirane održati postojeći status quo. U domeni stavova prema pretilima postavke bi ove teorije mogla podržati istraživanja koja pokazuju kako pretile osobe sebe vide u negativnom svjetlu (npr. Crocker, Cornwell i Major, 1993). Takvi su nalazi vjerojatno odraz stavova, vjerovanja i vrijednosti internaliziranih u djetinjstvu, a koje ima većina populacije - uključujući i pretile - primjerice, vjerovanje u pravedan svijet ili atribucije pretilosti.

Istraživanja u pogledu rodnih razlika u izraženosti negativnog stava prema pretilima ne daju sasvim jasne rezultate, no nekoliko novijih studija sugerira da su muškarci skloniji iskazivati nesviđanje prema pretilima nego što su to sklone žene (Lieberman, Tybur i Latner, 2012). Moguće je da su žene osjetljivije na društveni pritisak koji se stvara u pogledu mršavosti jer su i same potencijalna žrtva negativnog stava prema pretilima, u puno većoj mjeri nego muškarci. To ih općenito čini više 
empatičnima prema osobama prekomjerne težine. S druge strane, žene u istraživanjima češće izražavaju strah od debljine nego muškarci (Levitt, 2004).

Stereotipi, kao spoznajna sastavnica stava, imaju najveći utjecaj na diskriminaciju pretilih osoba (Finkelstein i sur., 2007). Pretile se osobe češće smatra lijenima, usamljenima, neinteligentnima, nemoralnima, neiskrenima (npr. Glenn i Chow, 2002; Polinko i Popovich, 2001; Puhl, Schwartz i Brownell, 2005), manje produktivnima, pasivnima, neodlučnima, manje uspješnima, nesretnima, manje agresivnima, manje samodiscipliniranima i nepopularnima (Tiggemann i Rothblum, 1988). Osim toga, pretile se osobe vide kao manje atraktivni i manje poželjni partneri u socijalnim i poslovnim situacijama (Hebl, Ruggs, Singletary i Beal, 2008). Specifično, u poslovnim situacijama suradnici percipiraju svoje pretile kolege kao lijene, nekompetentne, neuredne, nemarne i neljubazne, smatraju da imaju loše radne navike, sporije razmišljaju, rjeđe dolaze na posao te da su loš uzor ostalima (Paul i Townsend, 1995; Roehling, 1999; Rudolph, Wells, Weller i Baltes, 2009). Jasno je da će takvi stereotipi imati velikog utjecaja na zapošljavanje pretilih osoba kao i na njihovo napredovanje. Tako je utvrđeno da čak i uz jednake sposobnosti i prijašnje radno iskustvo pretila osoba ima puno manje mogućnosti da će dobiti posao nego osoba prosječne težine (Flint i sur., 2016; Pingitore, Dugoni, Tindale i Spring, 1994). Istraživanja su također pokazala da postoji razlika u prosječnoj plaći pretilih osoba $i$ osoba prosječne težine (npr. Pagan i Davila, 1997; Register i Williams, 1990) te da pretile osobe imaju manje prilika za napredovanje i češće su otpuštane, čak i kada su procijenjene kao visoko radno uspješne (Puhl i Heuer, 2009).

Iako istraživanja potvrđuju da se pretile osobe uistinu percipiraju negativnije nego osobe prosječne težine, ni jedno od navedenih istraživanja nije ispitalo percipiraju li se pretile osobe drugačije na pet temeljnih dimenzija ličnosti ili se negativna percepcija odnosi samo na specifična ponašanja u određenim, obično poslovnim, okolnostima. Stoga je u ovom istraživanju ispitano iskazuje li se negativan stav prema pretilima i stereotipom vezanim uz pet temeljnih dimenzija ličnosti prema Petofaktorskom modelu (engl. Big Five). Moguće je da su stereotipi o specifičnim ponašanjima pretilih osoba zapravo odraz stereotipa o dimenzijama ličnosti pretilih osoba; primjerice, ako se pretila osoba percipira manje savjesnom, to može rezultirati očekivanjem da će biti neuredna, nemarna ili sklona kašnjenju.

Finkelstein i suradnice (2007) su u SAD-u pokazale da je u radnom okruženju predrasuda prema pretilima izražena već pri samom zapošljavanju (u selekcijskoj situaciji), i to posebno kod zanimanja nižeg statusa, te u slučaju kad se percipira da osoba ima manje iskustva u radu. Metoda kojom su se pritom koristile bila je videosnimka intervjua za posao u kojem sudjeluje ili pretila osoba ili osoba prosječne težine. U ovom se istraživanju željela provjeriti univerzalnost negativnog stava prema pretilima utvrđena $u$ američkom kontekstu u području zapošljavanja. Drugim riječima, željelo se ispitati iskazuje li se negativan stav kod zapošljavanja na sličan način i u hrvatskom kontekstu, te javlja li se već i na temelju čitanja hipotetskog životopisa kandidata za posao. 
U ovo je istraživanje uključena i varijabla desničarske autoritarnosti. Desničarska se autoritarnost pokazala kao jedan je od snažnih prediktora negativnih rasnih stavova (npr. Heaven i Bucci, 2001) i stavova prema homoseksualcima (npr. Goodman i Moradi, 2008). Odnosi se na sklonost pokoravanja autoritetu, konvencionalnost (sklonost priklanjanja društvenim normama i konvencijama), te sklonost agresivnim reakcijama prema ljudima koji ne poštuju društvene norme i konvencije. Kako suvremeni pristupi objašnjenju međugrupnih stavova sve više teže sveobuhvatnosti te uključuju širok aspekt dispozicijskih i socijalizacijskih faktora, desničarska se autoritarnost, u novijim istraživanjima, gotovo standardno uključuje među odrednice međugrupnih stavova (Nelson, 2009). Budući da desničarska autoritarnost dosad nije ispitivana u kontekstu pretilosti, u ovom je istraživanju provjereno je li povezana i s negativnim stavom prema pretilim osobama.

\section{Eksplicitni i implicitni stavovi}

Zbog osjetljivosti eksplicitnih mjera na socijalno poželjno odgovaranje kao alternativni se način ispitivanja stavova sve češće koriste implicitne mjere, koje smanjuju socijalnu poželjnost u odgovorima. Najčešće je korištena implicitna mjera Test implicitnih asocijacija (IAT), koji se temelji na vremenu reakcije. Međutim, De Houwer (2006) u svom pregledu navodi kako su implicitne mjere stavova korištene $\mathrm{u}$ istraživanjima zapravo vrlo heterogene te se razlikuju prema tome u kojem su smislu (aspektu) implicitne. Mjere mogu biti implicitne u aspektu da: a) sudionici ne znaju što se mjerom ispituje, b) sudionici znaju (ili su svjesni) što se mjerom ispituje, ali ne mogu kontrolirati svoju reakciju ili c) sudionici su svjesni što se ispituje i mogu kontrolirati reakciju, ali nisu svjesni da imaju negativan stav. Nadalje, naglašava kako mjera ne mora biti u svim aspektima implicitna da bi se zvala implicitnom, već barem u jednom aspektu, stoga istraživači moraju jasno specificirati u kojem je smislu mjera implicitna. Zaključuje da je ono što je zajedničko svim implicitnim mjerama to da se "sudionike ne pita direktno za samoprocjenu vlastitog stava ili kognicije" (str. 20).

Glavna je prednost implicitnih mjera to što više koreliraju s ponašanjem od eksplicitnih mjera (McConnell i Liebold, 2001; Rudman, Greenwald, Mellott i Schwartz, 1999). Međutim, uz implicitne se mjere vežu i određene kritike, primjerice ispitivanje kulturalnih vjerovanja te niska test-retest pouzdanost. Korelacije između rezultata na eksplicitnim i implicitnim mjerama kreću se od nultih (Dovidio, Kawakami i Gaertner, 2002) do niskih (McConnell i Liebold, 2001), ovisno o tome koliko je tema kontroverzna. Bessenhoff i Sherman (2000) nisu utvrdili povezanost rezultata na implicitnim i eksplicitnim mjerama stavova prema pretilim osobama, što tumače kao posljedicu obuhvaćanja različitih aspekata stava. U skladu se s time pokazalo da je općenito povezanost eksplicitnih i implicitnih metoda moderirana stupnjem njihove sličnosti, ali i koliko je u procjenu uključeno osobno iskustvo $\mathrm{s}$ predmetom stava (Nosek, 2005). 
Kako u istraživanjima dosad gotovo uopće nije provjeravan stav prema pretilima implicitnim mjerama, u ovom je istraživanju korištena eksperimentalna manipulacija hipotetskim životopisom kandidata za posao kojom je izraženost negativnog stava prema pretilima ispitana indirektno. Prema kategorizaciji De Houwera (2006) korištena je mjera koja je implicitna u pogledu toga da sudionici nisu znali (nisu bili svjesni) što se tom mjerom ispituje. Međutim, kako se na stavove o pretilim osobama još uvijek ne gleda jednako negativno kao na ostale međugrupne stavove te kako određen postotak ljudi otvoreno iskazuje ovaj negativni stav, korištena je i eksplicitna metoda - skala stavova prema pretilim osobama.

\section{Pomagačke struke i rad sa stigmatiziranim skupinama}

Socijalni radnici i psiholozi pomagačke su profesije koje, osim što rade $\mathrm{s}$ ljudima različite dobi $\mathrm{i}$ socioekonomskog statusa, djeluju u brojnim važnim područjima njihova života, kao što su obrazovanje i zapošljavanje, te im pružaju potporu u savjetodavnom radu. Kako populacija pretilih osoba u svijetu, pa tako i u Hrvatskoj, sve više raste (Ministarstvo zdravstva i socijalne skrbi Republike Hrvatske, 2010), pretile su osobe sve češći korisnici usluga psihologa i socijalnih radnika. Također, psiholozi najčešće provode selekcijske postupke za zapošljavanje, a socijalni radnici većinu vremena rade s nezaposlenima. Djelatnici obiju struka trebali bi se u svom radu ograditi od procjenjivanja klijenata na temelju njihove pripadnosti stigmatiziranoj i/ili diskriminiranoj skupini, pa tako i skupini pretilih osoba. Nažalost, istraživanja pokazuju da to često nije praksa. Primjerice, Soto, Armendariz-Anguiano, Bacardí-Gascón i Jiménez Cruz (2014) utvrdili su da studenti psihologije u Meksiku imaju negativne stavove kao i malo znanja o pretilosti te uz pretile osobe vezuju karakteristike poput manjka samokontrole, nesigurnosti i lijenosti. Također, Puhl, Luedicke i Grilo (2014) utvrdili su da psiholozi smatraju kako bi pretile osobe u tretmanu bile nemotivirane za promjenu i ne bi slijedile upute.

Unatoč takvim nalazima u Hrvatskoj dosad nisu ispitivani stavovi prema pretilima kod pomagačkih struka, stoga se to odlučilo provjeriti u ovom istraživanju ispitivanjem stavova studenata nekih pomagačkih usmjerenja. Negativni bi stavovi mogli rezultirati smanjenim angažmanom $u$ radu i smanjenim poštovanjem prema klijentu te stereotipnim očekivanjima da će se klijent ponašati karakteristično za skupinu kojoj pripada (Urbanc, 2006). Osim toga, negativna iskustva sa zdravstvenim djelatnicima čine pretile osobe manje sklone traženju zdravstvene pomoći kada im je ona potrebna (Mold i Forbes, 2013; Phelan i sur., 2015). Rezultati bi ovog istraživanja, stoga, mogli poslužiti za povećavanje svijesti o negativnom stavu prema pretilim osobama kod pomagačkih struka u Hrvatskoj i kreiranje intervencija za smanjenje takvog stava. 


\section{Cilj istraživanja}

Cilj je ovog istraživanja ispitati stav prema pretilim osobama kod studenata nekih pomagačkih struka u Hrvatskoj. Stav je ispitan eksperimentalnom manipulacijom fotografije osobe kojoj je varirana težina (implicitna mjera) i upitnikom (eksplicitna mjera), a analizirana je i sukladnost rezultata na ove dvije mjere.

Pretpostavljeno je da će sudionici iskazivati negativan stav prema pretilim osobama i na eksplicitnoj i na implicitnoj mjeri. Negativan će se stav očitovati u negativnijim procjenama pretile osobe $u$ odnosu na osobu prosječne težine u pogledu njezine radne uspješnosti, u negativnijoj procjeni nekih aspekata ličnosti te u nižem rezultatu na upitničkoj mjeri stava. Pretpostavljena je i pozitivna povezanost desničarske autoritarnosti i negativnog stava prema pretilima. Konačno, očekivana je niska pozitivna povezanost rezultata na implicitnoj i eksplicitnoj mjeri stava prema pretilima.

\section{Metoda}

\section{Sudionici}

U istraživanju je sudjelovalo ukupno 429 sudionika, studenata prve, druge i treće godine preddiplomskog studija psihologije na Filozofskom fakultetu u Zagrebu $(N=201)$ te studenata prve i druge godine preddiplomskog studija socijalnog rada na Studijskom centru socijalnog rada Pravnog fakulteta u Zagrebu $(N=228)$. U čitavom je uzorku znatno više žena (89.3\%), nešto više na socijalnom radu (95.6\%) nego psihologiji (82\%). Prosječna je dob sudionika 20.16 godina $\left(M_{\text {psihologija }}=20.35\right.$; $M_{\text {socijalni rad }}=19.98$ ).

\section{Eksperimentalna manipulacija}

Podražajni se materijal sastojao od hipotetskog životopisa kandidata za posao s fotografijom. Radilo se o životopisu ženske osobe učestalog imena i prezimena (Ivana Horvat), visoke stručne spreme (diplomirana pravnica). Eksperimentalna se manipulacija sastojala $u$ promjeni fotografije uklopljene $u$ životopis: eksperimentalna je grupa dobila životopis s fotografijom pretile osobe, a kontrolna grupa životopis s fotografijom osobe prosječne težine (Slika 1.). U oba se slučaja radilo o fotografiji iste osobe koja je uređena u online-programu Photofunia (Photofunia, n.d.), tako da je osobi varirana težina. Na vrhu stranice, prije samog životopisa, nalazio se sljedeći opis: "Hrvatski Telekom objavio je natječaj za novootvoreno mjesto pravnika. Na oglas se javilo 50 osoba sličnih kompetencija i podjednakoga radnog iskustva. U nastavku se nalazi životopis Ivane Horvat, jedne od kandidatkinja". Kako bi životopis izgledao autentično, osmišljen je na temelju 
opisa posla pravnika u elektroničkom izdanju Vodiča kroz zanimanja (Šverko, 1998). Opis kompetencija i radnih zadataka u životopisu osmišljen je tako da bude vrlo općenit te da se iz njega ne može puno zaključiti o stvarnim karakteristikama kandidata, već da se procjene moraju donositi na temelju dojma. Iako su i muškarci i žene žrtve predrasuda, korištena je fotografija ženske osobe jer istraživanja potvrđuju da pretilost ima negativnije posljedice za žene, i u socijalnim i u poslovnim situacijama (npr. Fikkan i Rothblum, 2012; Maranto i Stenoien, 2000). Fotografija osobe preuzeta je s internetske stranice Free Great Picture (Free Great Picture, n.d.), koja nudi slobodno preuzimanje i korištenje primjeraka različitih fotografija.
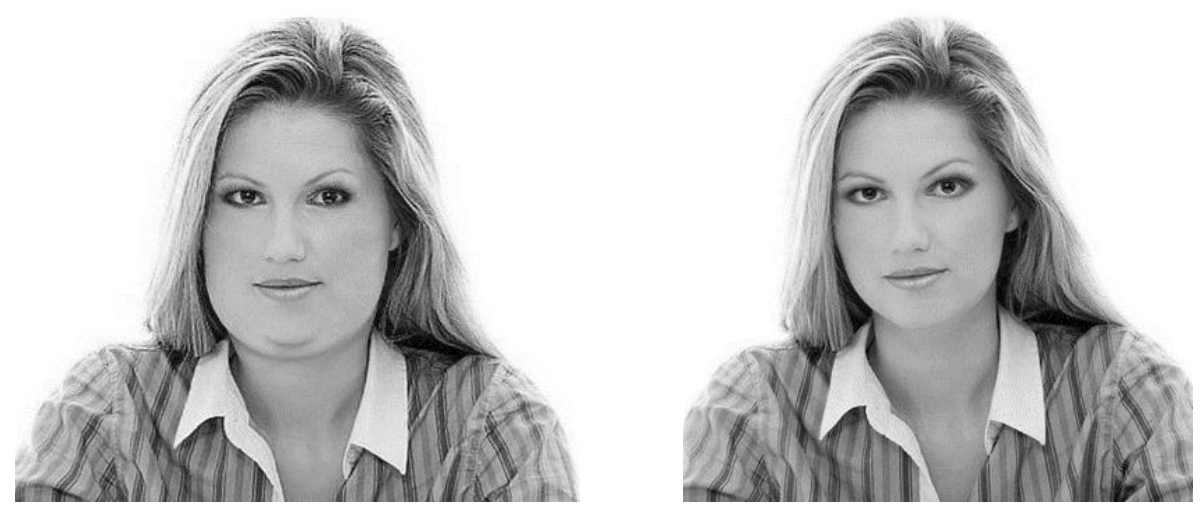

Slika 1. Fotografije pretile osobe i osobe prosječne težine korištene u hipotetskom životopisu.

\section{Mjerni instrumenti}

U istraživanju su korištene dvije skale za procjenu kandidata - skala procjene radne uspješnosti kandidata i skala procjene karakteristika ličnosti kandidata. Za procjenu potencijalne radne uspješnosti kandidata za posao korištena je prilagođena verzija skale procjene Finkelstein i suradnica (2007), prevedena na hrvatski jezik za potrebe ovog istraživanja te adaptirana (skraćena) na temelju predistraživanja. Prilagođena se verzija skale sastoji od 11 tvrdnji. Primjeri su tvrdnji "S entuzijazmom obavlja svoj posao", "Dobro kontrolira svoje emocije" ili "Snalažljiva je u iznenadnim situacijama". Zadatak je sudionika da na temelju fotografije i teksta životopisa na skali od 1 (nikad ili vrlo rijetko) do 5 (gotovo uvijek) za svaku tvrdnju procijene u kojoj se mjeri odnosi na kandidatkinju. Ukupni je rezultat na skali jednostavna linearna kombinacija odgovora na pojedinim tvrdnjama. Viši ukupni rezultat označava pozitivniju procjenu radne učinkovitosti osobe prikazane u životopisu. Faktorska analiza metodom glavnih komponenata s rotacijom Varimax na završnoj verziji skale pokazala je postojanje triju faktora, koji zajedno objašnjavaju 59.2\% varijance. Tri faktora sadržajno odgovaraju faktorima koje su utvrdile Finkelstein i suradnice (2007) - kapacitet izvedbe, stabilnost i 
prilagodljivost ${ }^{1}$. Pouzdanost unutarnje konzistencije završne verzije skale iznosi $\alpha=$ .83 .

Za procjenu je karakteristika ličnosti kandidata, za potrebe ovog istraživanja, konstruirana kratka skala prema petofaktorskom modelu ličnosti, a po uzoru na IPIP $100^{2}$ (The International Personality Item Pool) (Goldberg, 1999). Skala sadrži 20 čestica na 5 dimenzija (svaka dimenzija ima po 4 čestice). Primjer je čestice za dimenziju ekstraverzije "Voli se družiti s ljudima", za dimenziju emocionalne stabilnosti "Lako mijenja raspoloženja", za dimenziju savjesnosti "Na vrijeme izvršava obaveze", za dimenziju ugodnosti "Rado pomaže drugima" te za dimenziju otvorenosti "Razmišlja izvan okvira". Zadatak je sudionika da na temelju fotografije i teksta životopisa na skali od 1 (nikad ili vrlo rijetko) do 5 (gotovo uvijek) za svaku tvrdnju procijene u kojoj se mjeri odnosi na kandidatkinju. Nakon rekodiranja obrnuto okrenutih čestica rezultat se za svaku dimenziju računa kao jednostavna linearna kombinacija odgovora na svakoj tvrdnji te dimenzije. Viši ukupni rezultat na pojedinoj dimenziji označava da se osoba na njoj pozitivnije procjenjuje. Faktorska analiza metodom glavnih komponenata s rotacijom Varimax potvrdila je postojanje pet dimenzija, koje sadržajno odgovaraju petofaktorskom modelu. Pouzdanost dimenzija/podljestvica iznosi: za ekstraverziju $\alpha=.70$; za savjesnost $\alpha=$ .77; za emocionalnu stabilnost $\alpha=.76$; za otvorenost k iskustvima $\alpha=.71$; za ugodnost $\alpha=.73$ ).

U ovom je istraživanju korištena Kratka verzija skale desničarske autoritarnosti (Short version of the Right-Wing Authoritarianism (RWA) Scale; Zakrisson, 2005; hrv. adaptacija Ćepulić i Tomić, 2013). Primjeri su čestica iz skale "Tradicionalni običaji i vrijednosti još su uvijek najbolje smjernice za život", "Podaci pokazuju da bismo trebali strože kažnjavati zločine i seksualni nemoral kako bismo održali red i mir". Skala sadrži 15 tvrdnji na koje ispitanici odgovaraju na skali Likertova tipa od 1 (uopće se ne slažem) do 7 (u potpunosti se slažem). Nakon rekodiranja obrnuto okrenutih čestica ukupni se rezultat računa kao jednostavna linearna kombinacija svih odgovora na skali. Minimalni je mogući rezultat 15, a maksimalni 105. Viši rezultat označava manju desničarsku autoritarnost. Utvrđeno je da skala objašnjava značajan udio varijance etničke (ne)tolerancije, rasizma i seksizma (Rattazzi, Bobbio

\footnotetext{
${ }^{1}$ Iako je skala originalno zamišljena kao multidimenzionalna skala s više podljestvica, autori preporučuju računanje i korištenje ukupne mjere kao indikatora izraženosti negativnog stava (Finkelstein i sur., 2007).

${ }^{2}$ Budući da, koliko je nama poznato, u istraživanjima diskriminacije pri selekcijskom postupku u Hrvatskoj nisu dosad korišteni upitnici ličnosti, u ovom je istraživanju konstruirana posebna skala za tu svrhu. Kako su hrvatske verzije skala ličnosti relativno dugačke (npr. najkraća verzija IPIP-a na hrvatskom je IPIP 50), zbog ekonomičnosti je za potrebe ovog istraživanja konstruirana vrlo kratka skala od samo 20 čestica, koja je provjerena u preliminarnom istraživanju $(N=65)$. Pouzdanost pet dimenzija u predistraživanju iznosi: za ekstraverziju $\alpha=.77$; za savjesnost $\alpha=.66$; za emocionalnu stabilnost $\alpha=.53$; za otvorenost ka iskustvima $\alpha=.74$; za ugodnost $\alpha=.74$ ).
} 
i Canova, 2007). Pouzdanost unutarnje konzistencije hrvatske verzije skale iznosi $\alpha$ $=.88$. U ovom je istraživanju skala također pokazala visoku pouzdanost $(\alpha=.84)$, a faktorska analiza metodom glavnih komponenata s Varimax-rotacijom potvrdila je jednofaktorsko rješenje.

Skala stavova prema pretilim osobama (The Attitudes Toward Obese People Scale-ATOP; Allison, Basile i Yuker, 1991) instrument je za mjerenje eksplicitnih stavova i percepcije pretilih osoba u društvu, koji je za potrebe ovog istraživanja preveden na hrvatski jezik. Primjeri čestica u skali su "Pretile osobe ne bi trebale očekivati da će imati normalan život", "Većina osoba normalne težine ne bi voljela stupiti u brak s pretilom osobom", "Jako pretile osobe su obično neuredne". Sastoji se od 20 tvrdnji, a zadatak je sudionika da procijeni svoj stupanj slaganja sa svakom tvrdnjom na skali Likertova tipa od 6 stupnjeva, pri čemu se procjene kreću od -3 ( $u$ potpunosti se ne slažem) do +3 (u potpunosti se slažem). Nakon rekodiranja obrnuto okrenutih čestica ukupni se rezultat izražava kao linearna kombinacija rezultata na pojedinim tvrdnjama te se na njega dodaje vrijednost 60 (minimalni je rezultat 0 , a maksimalni 120). Viši rezultat označava pozitivniji stav prema pretilim osobama. Pouzdanost skale kreće se između .80 i .84 (Allison i sur., 1991). Skala je pokazala visoku pouzdanost i u preliminarnom istraživanju $(\alpha=.81)$ i u glavnom istraživanju $(\alpha=.83)$. Na kraju se upitnika od sudionika tražilo da navedu spol i dob.

\section{Postupak}

Svi su sudionici potpisali informirani pristanak za sudjelovanje u istraživanju prije početka ispunjavanja upitnika.

\section{Preliminarno istraživanje}

Preliminarno je istraživanje provedeno u studenom 2014. godine na 65 studenata prve godine preddiplomskog studija sociologije na Filozofskom fakultetu u Zagrebu. Svrha je preliminarnog istraživanja bila provjera učinkovitosti eksperimentalne manipulacije (životopisa hipotetskog kandidata za posao kao podražajnog materijala) i validacija skala za procjenu kandidata (skale procjene radne učinkovitosti i skale procjene karakteristika ličnosti). Sudionici su ispunjavali i skalu stavova prema pretilim osobama (ATOP), kako bi se provjerila pouzdanost hrvatskoga prijevoda skale.

\section{Glavno istraživanje}

Postupak je prikupljanja podataka proveden u vremenskom razdoblju od tri tjedna tijekom siječnja i ožujka 2015. godine. Podaci su prikupljeni grupno vođenim ispitivanjem na Filozofskom fakultetu u Zagrebu na studiju psihologije te na Pravnom fakultetu u Zagrebu na studiju socijalnog rada. Na svakom je od fakulteta polovica seminarskih grupa bila eksperimentalna skupina, a polovica kontrolna 
skupina. Prije ispunjavanja upitnika sudionicima je naglašeno kako je sudjelovanje $\mathrm{u}$ istraživanju dobrovoljno i potpuno anonimno. Nakon toga su podijeljeni upitnici te je sudionicima objašnjen postupak ispitivanja. Kako ne bi znali pravu svrhu istraživanja, rečeno im je da se provodi istraživanje prosudbi o ljudima prilikom zapošljavanja. Na prvoj se stranici upitnika nalazio informirani pristanak za sudjelovanje $u$ istraživanju, koji su sudionici pročitali i potpisali. Kako se ne bi mogli povezati individualni rezultati s imenom sudionika, sudionici su otrgnuli informirani pristanak od ostatka upitnika, koji je pokupljen prije početka rješavanja. Na prvoj se stranici upitnika nalazio životopis osobe (kandidata za posao) i fotografija. Sudionici su prvo davali procjene radne učinkovitosti i ličnosti kandidata za posao, a zatim su ispunili kratku skalu desničarske autoritarnosti, skalu stavova prema pretilim osobama i na kraju sociodemografske podatke. Ukupno je trajanje ispitivanja bilo 10 do 15 minuta.

\section{Rezultati}

U svrhu ispitivanja stava prema pretilima na implicitnoj mjeri korištena je složena analiza varijance $2 \times 2$, pri čemu su nezavisne varijable bile tjelesna težina osobe na fotografiji (pretila osoba ili osoba prosječne težine) i vrsta studija procjenjivača (psihologija ili socijalni rad), a zavisna je varijabla bila prosječni rezultat na skali procjene radne uspješnosti, odnosno prosječni rezultati na pojedinim podljestvicama/dimenzijama skale procjene karakteristika ličnosti. Rezultati su složene analize varijance za zavisnu varijablu procjene radne uspješnosti prikazani u Tablici 1.

Tablica 1.

Rezultati složene analize varijance za razlike u prosječnim procjenama radne uspješnosti kandidata ovisno o tjelesnoj težini osobe na fotografiji (pretila osoba ili osoba prosječne težine) i vrsti studija procjenjivača (psihologija ili socijalni rad)

\begin{tabular}{lcccc}
\hline & $N$ & $M(S D)$ & $F$ & $\eta^{2}$ \\
\hline pretila osoba & 210 & $36.32(5.68)$ & $17.62^{* *}$ & .04 \\
osoba prosječne težine & 219 & $38.68(5.84)$ & & \\
psihologija & 201 & $36.52(5.32)$ & $11.14^{\text {*** }}$ & .03 \\
socijalni rad & 228 & $38.41(6.19)$ & .05 & .00 \\
interakcija & & & .05 & \\
\hline
\end{tabular}

${ }^{* *} p<.01$.

Utvrđen je statistički značajan glavni efekt tjelesne težine osobe na fotografiji, pri čemu su sudionici koji su dobili fotografiju pretile osobe procjenjivali radnu uspješnost kandidata slabijom od sudionika koji su dobili fotografiju osobe prosječne težine. 


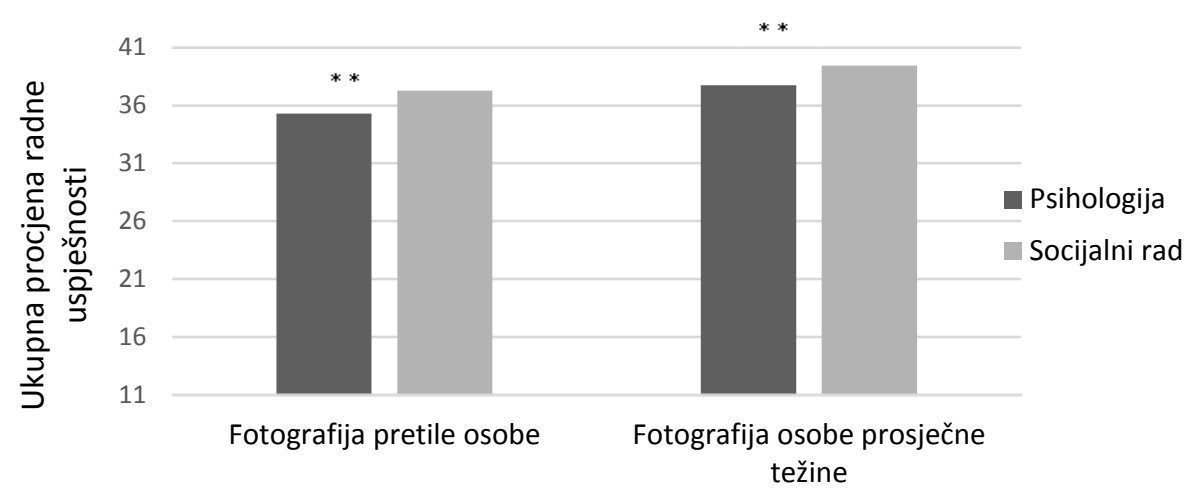

Slika 2. Prosječne procjene radne uspješnosti kandidata ovisno o tjelesnoj težini osobe na fotografiji i vrsti studija procjenjivača.

Utvrđen je i statistički značajan glavni efekt vrste studija procjenjivača, pri čemu su sudionici studenti psihologije procjenjivali radnu uspješnost kandidata općenito slabijom od sudionika studenata socijalnog rada, neovisno o tjelesnoj težini osobe na fotografiji. Za oba su glavna efekta dobivene male veličine efekta (Cohen, 1988). Rezultati pokazuju da nije utvrđena značajna interakcija tjelesne težine osobe na fotografiji i vrste studija. Dobiveni rezultati prikazani su i grafički na Slici 2.

Rezultati složene analize varijance za zavisnu varijablu procjena dimenzija ličnosti prikazani su u Tablici 2. Utvrđen je statistički značajan glavni efekt tjelesne težine osobe na fotografiji na dimenzijama ekstraverzije, emocionalne stabilnosti i otvorenosti, pri čemu je pretila osoba procijenjena kao manje ekstravertirana, manje emocionalno stabilna i manje otvorena. Za dimenziju emocionalne stabilnosti dobiven je umjereni efekt, a za ekstraverziju i otvorenost mali efekt (Cohen, 1988). Utvrđen je i statistički značajan glavni efekt vrste studija procjenjivača na dimenzijama savjesnosti, ugodnosti i otvorenosti, pri čemu je za savjesnost i ugodnost, dobiven mali, a za otvorenost umjereni (Cohen, 1988). Pri tome su na sve tri dimenzije sudionici studenti psihologije davali niže procjene nego sudionici studenti socijalnog rada. Međutim, ni jedna interakcija grupe i fakulteta nije značajna što upućuje na to da, jednako kao i na skali radne uspješnosti, studenti psihologije daju niže procjene i za osobe prosječne težine i za pretile osobe. 


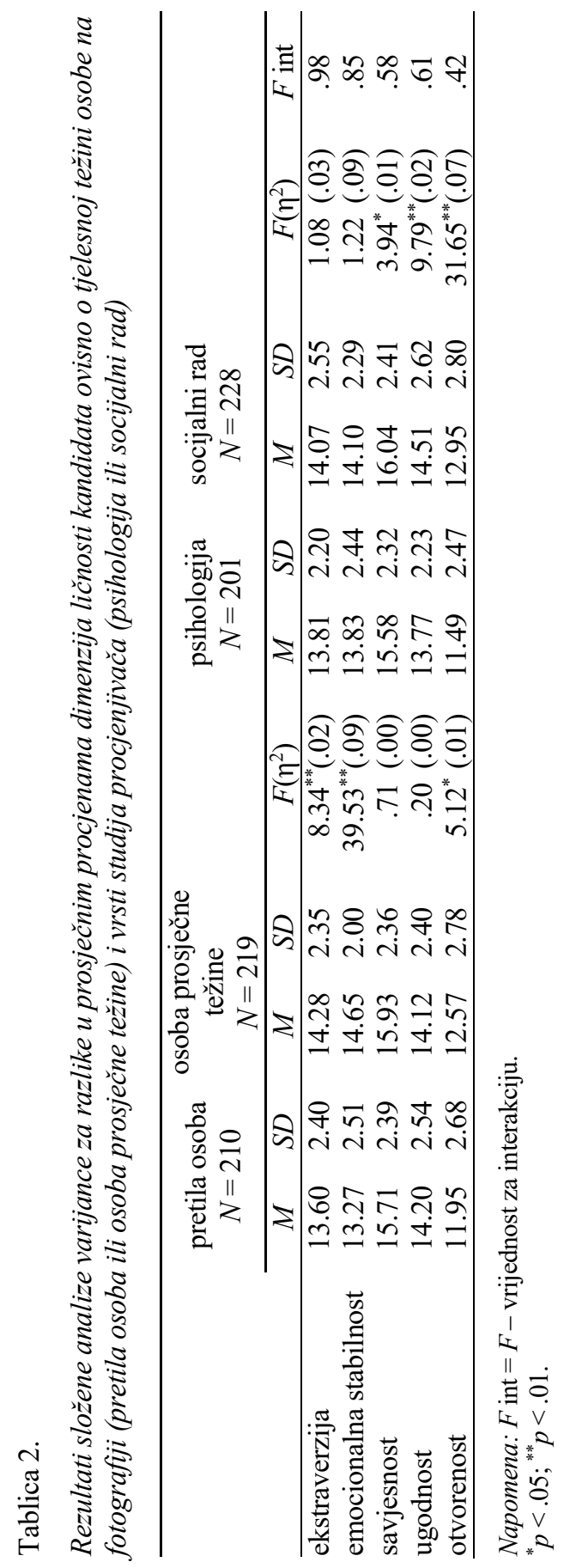




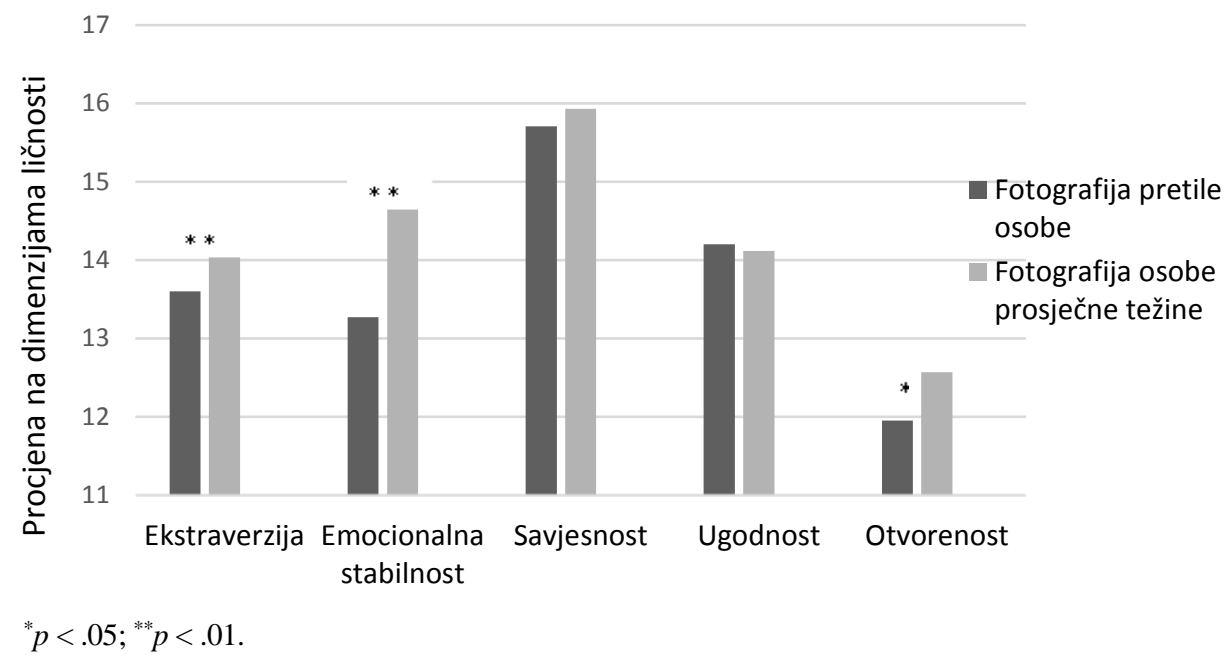

Slika 3. Prosječne procjene studenata psihologije i socijalnog rada pri procjenjivanju ličnosti ovisno o tjelesnoj težini osobe na fotografiji i vrsti studija procjenjivača.

Nadalje, na skali desničarske autoritarnosti sudionici u prosjeku ostvaruju umjereno visok rezultat $(M=69.57$; teorijski raspon: $15-105)$. Pri tome studenti psihologije ostvaruju statistički značajno viši rezultat nego studenti socijalnog rada $\left(M_{\text {psihologija }}=73.75 ; S D_{\text {psihologija }}=13.55 ; M_{\text {socijalni rad }}=65.39 ; S D_{\text {socijalni rad }}=12.49 ; t=\right.$ $6.65 ; p<.01)$. Na skali stavova prema pretilima sudionici u prosjeku ostvaruju umjereno visok rezultat. Drugim riječima, iskazuju umjerenu razinu negativnog stava $(M=79.93$; teorijski raspon: $0-120$; viši rezultat označava pozitivniji stav). Pri tome studenti psihologije postižu nešto niži rezultat, odnosno iskazuju nešto višu razinu negativnog stava od studenata socijalnog rada $\left(M_{\text {psihologija }}=78.78 ; S D_{\text {psihologija }}=\right.$ $\left.11.53 ; M_{\text {socijalni rad }}=81.07 ; S D_{\text {socijalni rad }}=10.61 ; t=2.14 ; p<.05\right)$. S obzirom na to da istraživanja sugeriraju da su muškarci nešto skloniji iskazivati nesviđanje prema pretilima nego što su to sklone žene (Lieberman, Tybur i Latner, 2012), a da je u uzorku studenata psihologije veći broj muškaraca nego u uzorku socijalnog rada, provedena je analiza kovarijance u kojoj je kao kovarijata uzet spol sudionika. Rezultati su pokazali da razlika u prosječnim procjenama ovisno o vrsti studija prestaje biti značajna ako kontroliramo varijablu spola sudionika $(F=2.67 ; p>.05)$. Spol je kontroliran i kod analiza razlika na ostalim skalama, no rezultati s kontrolom spola i oni bez kontrole nisu se razlikovali. Kako bi se provjerilo razlikuju li se kontrolna $\mathrm{i}$ eksperimentalna skupina $\mathrm{u}$ početnom stavu prema pretilima (u rezultatima na skali stavova prema pretilima), proveden je $t$-test, koji je pokazao da se na toj varijabli grupe ne razlikuju $\left(M_{\text {pretila }}=36.32 ; S D_{\text {pretila }}=5.68 ; M_{\text {prosječna }}=38.68\right.$; $\left.S D_{\text {prosječna }}=5.84 ; t=0.29 ; p>.05\right)$.

Izračunati su i Pearsonovi koeficijenti korelacije između eksplicitne mjere i implicitnih mjera - i to onih na kojima su dobivene različite procjene između 
eksperimentalne i kontrolne grupe. Utvrđene su korelacije niske, ali značajne i u pozitivnom smjeru. Rezultat je na eksplicitnoj mjeri povezan s procjenom: radne uspješnosti, ekstraverzije, emocionalne stabilnosti i otvorenosti. Dakle, sudionici koji u većoj mjeri iskazuju eksplicitni negativni stav, daju i negativnije procjene na implicitnim mjerama. Osim toga, provjerena je i korelacija rezultata na skali desničarske autoritarnosti s rezultatima na eksplicitnoj mjeri, za koju je utvrđen niski, ali značajni koeficijent korelacije $(r=.12, p<.05)$.

Tablica 3.

Prikaz korelacija između eksplicitnih i značajnih implicitnih mjera kod eksperimentalne skupine i kontrolne skupine

\begin{tabular}{|c|c|c|c|c|c|c|}
\hline & ATOP & ekstraverzija & $\begin{array}{l}\text { emocionalna } \\
\text { stabilnost }\end{array}$ & savjesnost & ugodnost & otvorenost \\
\hline \multirow{3}{*}{ TRM } & $.32^{* * *}$ & $.40^{* * *}$ & $.42^{* * *}$ & $.40^{* * *}$ & $.44^{* *}$ & $.58^{* * *}$ \\
\hline & .01 & $.38^{* *}$ & $.43^{* *}$ & $.41^{* *}$ & $.38^{* *}$ & $.59^{* *}$ \\
\hline & $.16^{*}$ & $.40^{* *}$ & $.45^{* *}$ & $.41^{* *}$ & $.40^{* *}$ & $.59^{* *}$ \\
\hline \multirow{3}{*}{ ATOP } & & $.23^{* *}$ & $.22^{* * *}$ & .08 & $.15^{*}$ & $.15^{* *}$ \\
\hline & - & $.15^{*}$ & $.03^{*}$ & .06 & .09 & .10 \\
\hline & & $.20^{* *}$ & $.13^{* *}$ & .07 & $.12^{*}$ & $.13^{* *}$ \\
\hline
\end{tabular}

Napomena. ATOP - skala stavova prema pretilim osobama, TRM - skala procjene radne uspješnosti kandidata. Vrijednosti pisane masnim slovima odnose se na eksperimentalnu skupinu, kosim slovima na kontrolnu skupinu, a standardnim slovima na sve sudionike zajedno.

${ }^{*} p<.05 ;{ }^{* *} p<.01$.

\section{Rasprava}

Cilj je ovog istraživanja bio ispitati eksplicitni i implicitni negativni stav prema pretilim osobama kod studenata nekih pomagačkih struka u Hrvatskoj. Dobiveni su rezultati potvrdili postavljene hipoteze. Sudionici su procjenjivali radnu uspješnost pretile osobe slabijom nego radnu uspješnost osobe prosječne težine te su procjenjivali pretilu osobu nepovoljnije na tri dimenzije ličnosti (manje socijalno poželjnim karakteristikama ličnosti). Takav je rezultat očekivan s obzirom na nalaze istraživanja koja su pokazala da se pretile osobe u različitim situacijama procjenjuju negativnije od osoba prosječne težine (npr. Rudolph i sur., 2009), a taj se efekt javlja i kod osoba pomagačkih struka (npr. Soto i sur., 2014). Premda dosad ne postoji sustavno razrađena i empirijski provjerena teorija stavova prema pretilima, pri tumačenju rezultata ovog istraživanja može poslužiti nekoliko širih teorijskih pristupa u području međugrupnih stavova. Jedno od mogućih objašnjenja utvrđenih razlika i kod procjena radne uspješnosti i kod procjena dimenzija ličnosti nudi nam teorija opravdavanja sustava (Jost i Banaji, 1994), koja pretpostavlja da su ljudi motivirani održati postojeći društveni status quo (u ovom slučaju visoki društveni 
status koji se vezuje uz vitke ljude). Takva je motivacija odraz stavova, vjerovanja i vrijednosti internaliziranih u djetinjstvu - primjerice, vjerovanje u pravedan svijet ili atribucije pretilosti. Ako se smatra da su pretili takvi svojom krivnjom te da je vitkost odgovornost svakog pojedinca, tada će osobu koja "odbija" udovoljiti standardima društva procijeniti manje pozitivno nego osobu prosječne težine. Također, dobiveni se rezultati mogu objasniti i teorijom međugrupnih emocija (Mackie i sur., 2000) pretile se osobe mogu percipirati pripadnicima grupe niskog statusa te izazvati specifične emocije (npr. ljutnju ili gađenje), koje dovode do negativnog stava, utvrđenog u ovom istraživanju. Dobiveni su rezultati u skladu i s evolucijskim pristupima međugrupnim stavovima (Neuberg i sur., 2000), koji naglašavaju kako negativni međugrupni stavovi imaju adaptivnu važnost smanjivanja prijetnje. Pretili bi ljudi mogli predstavljati prijetnju jer ih se vezuje uz fizičku bolest (nasuprot fizičkom zdravlju), stoga je stav prema njima negativan.

Dobiveni rezultati idu u prilog i pretpostavkama teorije sadržaja stereotipa (Fiske i sur., 2002), koja pretpostavlja da će stav prema pretilima biti negativan jer je sadržaj stereotipa prema pretilima negativan. Kako se pretilost smatra preprekom za socijalne odnose te kontrolabilnom osobinom, pretile će se osobe procjenjivati nisko i na dimenziji topline (nema zadovoljavajuće socijalne odnose) i na dimenziji kompetencije (nedostatak samokontrole), što je i utvrđeno u ovom istraživanju. Sudionici su pretilu osobu, u odnosu na osobu prosječne težine, procjenjivali manje povoljno na tri dimenzije ličnosti - ekstraverziji, emocionalnoj stabilnosti i otvorenosti. Možemo reći da dvije od tri navedene dimenzije ličnosti odgovaraju dvjema dimenzijama modela sadržaja stereotipa: ekstraverzija odgovara dimenziji topline, a emocionalna stabilnost dimenziji kompetencije. Nisko bi se na dimenziji kompetencije mogla nalaziti i dimenzija savjesnosti, međutim, u ovom istraživanju nije utvrđena razlika na toj dimenziji. Kako je u životopisu osobe koju su sudionici procjenjivali pisalo da se radi o pravnici, moguće je da sudionici nisu vjerovali da bi osoba koja nije savjesna uspjela završiti studij prava. Kada bi se radilo o nekom manje prestižnom zanimanju (primjerice, prodavačici u trgovini), možda bi se ta razlika pokazala značajnom. Zaključno, s obzirom na to da rezultati većim dijelom potkrepljuju opisane teorijske modele, možemo reći da ovo istraživanje daje i važan prilog nekim suvremenim teorijama međugrupnih stavova, odnosno proširuje primjenu tih teorija na stavove prema pretilima.

Kao objašnjenje dobivenih rezultata također može poslužiti i klasična teorija socijalnog učenja (Bandura, 1977). Mediji pretile osobe često opisuju kao neugodne, usamljene i čudne, a vrlo ih rijetko pokazuju u romantičnim vezama ili kao uspješne poslovne ljude (Whyte, 2010). Čest su mehanizam kako mediji prenose stereotipna vjerovanja iluzorne korelacije - ljudi su skloni uočavati odnose između događaja koji u stvari nisu povezani, onda kada su događaji ili ljudi istaknuti ili upadljivi (Hamilton, 1981). Takav pristrani i stereotipni medijski prikaz može dovesti do toga da ljudi primjenjuju negativne stereotipe o pretilim osobama koje su vidjeli $\mathrm{u}$ medijima na stvarne pretile osobe. Stoga možemo pretpostaviti da su i sudionici ovog 
istraživanja pod utjecajem medija koji prikazuju pretile osobe kao, na primjer, usamljene (niža ekstraverzija), pretjerano osjetljive (niža emocionalna stabilnost) te s malo interesa i osobnog razvoja (niža otvorenost) davali pretiloj osobi niže procjene na tim dimenzijama.

Za obje je zavisne varijable utvrđeno da studenti psihologije općenito daju niže procjene (i pretiloj osobi i osobi prosječne težine) nego studenti socijalnog rada. Moguće je da priroda područja socijalnog rada, koje stavlja naglasak na uvažavanje društvenih različitosti i rad s prvenstveno diskriminiranim skupinama ljudi, dovodi do toga da studenti socijalnog rada općenito imaju "blaže" prosudbe ljudi. Druga je mogućnost da studenti psihologije tijekom studija imaju veći fokus na procjenjivanje različitih osobina ljudi, a to iskustvo ih onda čini strožim pri davanju procjena. Unatoč utvrđenim razlikama u glavnom efektu strogosti u procjenama nije dobivena značajna interakcija vrste studija i grupe (eksperimentalne i kontrolne). Dobiveni rezultat upućuje na sličnost $\mathrm{u}$ iskazivanju negativnog stava studenata relativno srodnih, u ovom slučaju, pomagačkih struka. Takav nalaz ne iznenađuje ako pretpostavimo da sadržajno slične studije upisuju studenti sličnih profesionalnih preferencija i karakteristika ličnosti, a i da studiji srodnih polja na sličan način educiraju svoje studente.

Osim teorijskog, ovo istraživanje ima i značajan metodološki doprinos. Kako u istraživanjima dosad gotovo uopće nije provjeravan stav prema pretilima implicitnim mjerama, možemo reći da ovo istraživanje predstavlja jedan od pionirskih pokušaja zahvaćanja implicitnog stava prema ovoj socijalnoj grupi. Glavna je prednost implicitnih mjera to što više koreliraju s ponašanjem od eksplicitnih mjera (npr. McConnell i Liebold, 2001). Prema kategorizaciji De Houwera (2006) u ovom je istraživanju korištena mjera koja je implicitna u pogledu toga da sudionici nisu znali (nisu bili svjesni) što se tom mjerom ispituje jer je korišten hipotetski životopis kandidata za posao s fotografijom (dio sudionika imao je fotografiju pretile osobe, a dio osobe prosječne težine). Međutim, uz implicitne mjere vežu se i određene kritike, primjerice ispitivanje kulturalnih vjerovanja, niska test-retest pouzdanost, a dodatno opravdanje za eksplicitno mjerenje stava prema pretilima dolazi iz podataka o relativno otvorenom iskazivanju tog stava u društvu. Stoga je dodatni metodološki doprinos ovog istraživanja što je stav ispitan i eksplicitno te je provjerena međusobna povezanost implicitne i eksplicitne mjere.

Općenito, rezultati na eksplicitnoj mjeri pokazuju da studenti obiju vrsta studija iskazuju i eksplicitne negativne stavove prema pretilim osobama. Takav nalaz posebno zabrinjava s obzirom na podatke o tome da ljudi često socijalno poželjno odgovaraju i umanjuju negativne stavove na tim mjerama (Banaji i Greenwald, 1994). Čini se da su negativni stavovi prema pretilima toliko rašireni i normalizirani u našem društvu da ih studenti vjerojatno nemaju potrebu umanjivati i prikrivati. Iako je utvrđeno da studenti psihologije imaju višu razinu eksplicitnih negativnih stavova prema pretilima od studenata socijalnog rada, razlika se pokazala neznačajnom kada se kontrolirao spol sudionika. Spol je kontroliran jer je nešto veći omjer muških 
sudionika na psihologiji (18\%) nego socijalnom radu (4.4\%), a istraživanja sugeriraju da su muškarci skloniji iskazivati nesviđanje prema pretilima nego što su to sklone žene (Lieberman i sur., 2012).

U pogledu je povezanosti mjera dobivena niska pozitivna povezanost rezultata na eksplicitnoj mjeri i dvije implicitne mjere - procjeni radne uspješnosti kandidata i procjeni dimenzija ličnosti kandidata (značajna razlika za ekstraverziju, emocionalnu stabilnost i otvorenost). Drugim riječima, sudionici iskazuju negativan stav i na eksplicitnim i na implicitnim mjerama, ali povezanost rezultata na tim dvjema mjerama nije visoka. Dobiveni nalaz upućuje na to da su rezultati na ovim mjerama donekle sukladni, ali i da postoji "prikriveni" dio stava koji nije zahvaćen upitničkom mjerom jer na toj mjeri sudionici daju više socijalno poželjne odgovore. Visine su dobivenih povezanosti u skladu s postavljenom hipotezom, kao i s prijašnjim istraživanjima koja su se bavila povezanošću implicitnih i eksplicitnih mjera stavova (npr. Nosek, 2005). Korelacije između rezultata na eksplicitnim i implicitnim mjerama obično se kreću od nultih (Dovidio i sur., 2002) do niskih (McConnell i Liebold, 2001), ovisno o tome koliko je tema kontroverzna. Bessenhoff i Sherman (2000) nisu utvrdili povezanost rezultata na implicitnim i eksplicitnim mjerama stavova prema pretilim osobama, što tumače kao posljedicu obuhvaćanja različitih aspekata stava. U skladu s time, pokazalo se da je općenito povezanost eksplicitnih i implicitnih metoda moderirana stupnjem njihove sličnosti (Nosek, 2005). Stoga, iako se nalaz utvrđen u ovom istraživanju razlikuje od nalaza Bessenhoffa i Shermana (2000), možda su mjere korištene u ovom istraživanju uspjele obuhvatiti sličnije aspekte stava prema pretilima, što je i rezultiralo značajnom korelacijom.

Rezultati ovog istraživanja potvrdili su i hipotezu u pogledu povezanosti desničarske autoritarnosti i stava prema pretilima. Utvrđena je niska, ali značajna pozitivna korelacija - osobe koje u većoj mjeri poštuju društvene norme i konvencije iskazuju ujedno i negativniji stav prema pretilim osobama. Kako je u današnjem društvu vitkost (i briga o vlastitom izgledu) norma, možemo pretpostaviti da se na pretilost gleda kao na namjerno odstupanje od normi (kršenje normi). Kako je jedno od obilježja ljudi koji su visoko na autoritarnosti sklonost agresivnim reakcijama prema ljudima koji ne poštuju društvene norme i konvencije, dobiveni je smjer povezanosti desničarske autoritarnosti i stava prema pretilim osobama očekivan.

Provedeno istraživanje ima nekoliko metodoloških ograničenja. U prvom redu, situacija čitanja hipotetskog životopisa je vrlo artificijelna te, kako to nije dodatno provjereno, ne može se sa sigurnošću tvrditi da su se sudionici u potpunosti uživjeli u ulogu procjenjivača te se ne zna je li im životopis u istraživanju djelovao realistično. Uz to, istraživanje je provedeno na studentima, stoga je mogućnost generalizacije na opću populaciju ograničena. Treće je ograničenje vezano uz raspodjelu sudionika $\mathrm{u}$ grupe. $\mathrm{Na}$ oba je fakulteta istraživanje provođeno $\mathrm{u}$ seminarskim grupama. Kako se sudionici za kontrolnu i eksperimentalnu skupinu iz svake od seminarskih grupa nisu raspodijelili po slučaju, zapravo se ne može govoriti 
o pravom eksperimentalnom nacrtu. No, kako se eksperimentalna i kontrolna grupa ne razlikuju u početnom stavu, ipak se mogu opravdano uspoređivati rezultati između grupa i dobivene razlike u rezultatima na implicitnoj mjeri pripisati samo eksperimentalnoj manipulaciji. Naposljetku, u istraživanju su ispitani samo studenti nižih godina studija, pa bi valjalo provjeriti mijenja li se izraženost negativnog stava s vremenom, odnosno hoće li nalaz biti podjednak kad su uključeni i stariji studenti koji imaju više znanja o stereotipima, predrasudama i diskriminaciji. Međutim, zbog činjenice da su implicitni stavovi relativno otporni na promjenu (Nelson, 2009), može se pretpostaviti da bi se dobili slični rezultati i na studentima viših godina studija. Ovo bi istraživanje također valjalo i proširiti tako da uključuje druga pomagačka zanimanja (socijalne pedagoge, logopede, rehabilitatore, liječnike i medicinske sestre) te ostala društvena zanimanja (npr. odgojitelje i učitelje). Bilo bi dobro ispitati i druge korelate negativnog stava prema pretilima (osim desničarske autoritarnosti), primjerice, osobine ličnosti, doživljaj prijetnje ili međugrupne emocije.

Specifičnost stava prema pretilima očituje se u tome da je manje inhibiran socijalnom poželjnosti i otvoreno se iskazuje. Zbog toga treba senzibilizirati javnost, prepoznati utjecaj negativnog stava u raznim područjima života - od najranije dobi i školovanja, pa sve do diskriminacije na radnom mjestu, te poduzeti korake za pomak u pozitivnom smjeru. Brojna su strana istraživanja pokazala da je jedan od načina za smanjenje negativnog stava educiranje o sadržaju stava (npr. Pettijohn i Walzer, 2008). Stoga bi ovo istraživanje moglo poslužiti kao podloga za formiranje nastavnih sadržaja vezanih uz pretilost. Koliko nam je poznato, studente pomagačkih struka educira se samo o načinu na koji mogu pomoći klijentima da smanje tjelesnu težinu ili da izgrade bolju sliku o sebi. Sadržaj nastave trebao bi biti usmjeren i na stavove koje imamo o pretilim osobama - u pogledu stereotipa da su pretile osobe, primjerice, više emocionalno nestabilne ili predrasude da su manje radno učinkovite.

\section{Literatura}

Allison, D. B., Basile, V. C. i Yuker, H. E. (1991). The measurement of attitudes toward and beliefs about obese persons. International Journal of Eating Disorders, 10, 599-607.

Andreyeva, T., Puhl, R. M. i Brownell, K. D. (2008). Changes in perceived weight discrimination among Americans, 1995-1996 through 2004-2006. Obesity, 16(5), 11291134.

Banaji, M. R. i Greenwald, A. G. (1994). Implicit stereotyping and prejudice. U: M. P. Zanna i J. M. Olson (Ur.), The psychology of prejudice: The Ontario symposium (Vol. 7, str. 55-76). Mahwah, NJ: Erlbaum.

Bandura, A. (1977). Social learning theory. Englewood, NJ: Prentice-Hall.

Bessenhoff, G. R. i Sherman, J. W. (2000). Automatic and controlled components of prejudice toward fat people: Evaluation versus stereotype activation. Social Cognition, 18(4), 329353. 
Berk, L. (2005). Psihologija cjeloživotnog razvoja. Jastrebarsko: Naklada Slap.

Brownell, K. D., Puhl, R. M., Schwartz, M. B. i Rudd, L. (2005). Weight bias: Nature, consequences, and remedies. New York: Guilford Press.

Cohen, J. (1988). Statistical power analysis for the behavioral sciences (2nd ed.). New Jersey: Lawrence Erlbaum Associates.

Crandall, C. S. (1994). Prejudice against fat people: Ideology and self-interest. Journal of Personality and Social Psychology, 66(4), 882-894.

Crocker, J., Cornwell, B. i Major, B. (1993). The stigma of overweight: Affective consequences of attributional ambiguity. Journal of Personality and Social Psychology, $64,60-70$.

Ćepulić, D. B. i Tomić, I. (2013). Uloga rodnih uloga, seksističkih stavova i desničarske autoritarnosti u stavovima prema gej i lezbijskoj populaciji. Rad priopćen na 21 . Danima Ramira i Zorana Bujasa, 11.-13.4.2013. Zagreb, Hrvatska.

De Houwer, J. (2006). What are implicit measures and why are we using them. U: R. W. Wiers i A. W. Stacy (Ur.), The handbook of implicit cognition and addiction (str. 1128). Thousand Oaks, CA: Sage.

Dovidio, J. F., Kawakami, K. i Gaertner, S. L. (2002). Implicit and explicit prejudice and interracial interaction. Journal of Personality and Social Psychology, 82, 62-68.

Eisenberg, M. E., Neumark-Sztainer, D., Haines, J. i Wall, M. (2006). Weight-teasing and emotional well-being in adolescents: Longitudinal findings from Project EAT. Journal of Adolescent Health, 38, 675-683.

Fikkan, J. L. i Rothblum, E. D. (2012). Is fat a feminist issue? Exploring the gendered nature of weight bias. Sex Roles, 66(9-10), 575-592.

Finkelstein, L. M., Frautschy Demuth, R. L. i Sweeney, D. L. (2007). Bias against overweight job applicants: Further explorations of when and why. Human Resource Management, 46, 203-222.

Fiske, S. T., Cuddy, A. J. C., Glick, P. i Xu, J. (2002). A model of (often mixed) stereotype content: Competence and warmth respectively follow from perceived status and competition. Journal of Personality and Social Psychology, 82, 878-902.

Flint, S. W., Čadek, M., Codreanu, S. C., Ivić, V., Zomer, C. i Gomoiu, A. (2016). Obesity discrimination in the recruitment process: "You're not hired!". Frontiers in Psychology, 7, 647.

Free Great Picture. (n.d.). Preuzeto s http://www.freegreatpicture.com

Glenn, C. V. i Chow, P. (2002). Measurement of attitudes toward obese people among a Canadian sample of men and women. Psychological Reports, 91(2), 627-640.

Goldberg, L. R. (1999). A broad-bandwidth, public domain, personality inventory measuring the lower-level facets of several five-factor models. Personality Psychology in Europe, 7, 7-28. 
Goodman, M. B. i Moradi, B. (2008). Attitudes and behaviors toward lesbian and gay persons: Critical correlates and mediated relations. Journal of Counseling Psychology, 55, 371384.

Haines, J., Neumark-Sztainer, D., Eisenberg, M. E. i Hannan, P. J. (2006). Weight-teasing and disordered eating behaviors in adolescents: Longitudinal findings from Project EAT (Eating Among Teens). Pediatrics, 117, 209-215.

Hamilton, D. L. (1981). Illusory correlation as a basis for stereotyping. U: D. L. Hamilton (Ur.), Cognitive processes in stereotyping and intergroup behavior (str. 115-144). Hillsdale, NJ: Erlbaum.

Heaven, P. C. i Bucci, S. (2001). Right-wing authoritarianism, social dominance orientation and personality: An analysis using the IPIP measure. European Journal of Personality, $15,49-56$.

Hebl, M. R., Ruggs, E. N., Singletary, S. L. i Beal, D. J. (2008). Perceptions of obesity across the lifespan. Obesity, 16(2), 46-52.

Hunger, J. M., Major, B., Blodorn, A. i Miller, C. T. (2015). Weighed down by stigma: How weight-based social identity threat contributes to weight gain and poor health. Social and Personality Psychology Compass, 9(6), 255-268.

Janssen, I., Craig, W. M., Boyce, W. F. i Pickett, W. (2004). Associations between overweight and obesity with bullying behaviors in school-aged children. Pediatrics, 113(5), 1187 1194.

Jost, J. T. i Banaji, M. R. (1994). The role of stereotyping in system-justification and the production of a false consciousness. British Journal of Social Psychology, 33, 1-27.

Latner, J. D., O'Brien, K. S., Durso, L. E., Brinkman, L. A. i MacDonald, T. (2008). Weighing obesity stigma: The relative strength of different forms of bias. International Journal of Obesity, 32(7), 1145-1152.

Levitt, D. H. (2004). Drive for thinness and fear of fat among college women: Implications for practice and assessment. Journal of College Counseling, 7(2), 109-117.

Lieberman, D. L., Tybur, J. M. i Latner, J. D. (2012). Disgust sensitivity, obesity stigma, and gender: Contamination psychology predicts weight bias for women, not men. Obesity, 20(9), 1803-1814.

Mackie, D. M., Devos, T. i Smith, E. R. (2000). Intergroup emotions: Explaining offensive action tendencies in an intergroup context. Journal of Personality and Social Psychology, 79, 602-616.

Maranto, C. L. i Stenoien, A. F. (2000). Weight discrimination: A multidisciplinary analysis. Employee Responsibilities and Rights Journal, 12, 9-24.

McConnell, A. R. i Liebold, J. M. (2001). Relations between the Implicit Association Test, explicit racial attitudes, and discriminatory behavior. Journal of Experimental Social Psychology, 37, 435-442.

McHugh, M. C. i Kasardo, A. E. (2012). Anti-fat prejudice: The role of psychology in explication, education and eradication. Sex Roles, 66(9-10), 617-627. 
Ministarstvo zdravstva i socijalne skrbi Republike Hrvatske (2010). Akcijski plan za prevenciju i smanjenje prekomjerne tjelesne težine za razdoblje od 2010. do 2012. godine. Zagreb.

Mold, F. i Forbes, A. (2013). Patients' and professionals' experiences and perspectives of obesity in health-care settings: A synthesis of current research. Health Expectations, 16(2), 119-142.

Nelson, T. D. (2009). Handbook of prejudice, stereotyping, and discrimination. New York: Psychology Press.

Neuberg, S. L., Smith, D. M. i Asher, T. (2000). Why people stigmatize: Toward a biocultural framework. U: T. F. Heatherton, R. E. Kleck, M. R. Hebl i J. G. Hull (Ur.), The social psychology of stigma (str. 31-61). New York: Guilford.

Nosek, B. A. (2005). Moderators of the relationship between implicit and explicit evaluation. Journal of Experimental Psychology: General, 134(4), 565-584.

O'Brien, K. S., Latner, J. D., Ebneter, D. i Hunter, J. A. (2013). Obesity discrimination: The role of physical appearance, personal ideology, and anti-fat prejudice. International Journal of Obesity, 37(3), 455-460.

Pagan, J. A. i Davila, A. (1997). Obesity, occupational attainment, and earnings. Social Science Quarterly, 78, 756-770.

Paul, R. J. i Townsend, J. B. (1995). Shape up for ship out? Employment discrimination against the overweight. Employee Responsibilities and Rights Journal, 8(2), 133-145.

Pettijohn, T. F. II i Walzer, A. S. (2008). Reducing racism, sexism and homophobia in college students by completing a psychology of prejudice course. College Student Journal, 42(2), 459-468.

Phelan, S. M., Burgess, D. J., Yeazel, M. W., Hellerstedt, W. L., Griffin, J. M. i Ryn, V. M. (2015). Impact of weight bias and stigma on quality of care and outcomes for patients with obesity. Obesity Reviews, 16(4), 319-326.

PhotoFunia. (n.d.). Preuzeto s https://photofunia.com

Pingitore, R., Dugoni, B. L., Tindale, R. S. i Spring, B. (1994). Bias against overweight job applicants in a simulated employment interview. Journal of Applied Psychology, 79, 909-917.

Polinko, N. K. i Popovich, P. M. (2001). Evil thoughts but angelic actions: Responses to overweight job applicants. Journal of Applied Social Psychology, 31, 905-924.

Puhl, R. M., Andreyeva, T. i Brownell, K. D. (2008). Perceptions of weight discrimination: Prevalence and comparison to race and gender discrimination in America. International Journal of Obesity, 32, 992-1000.

Puhl, R. i Brownell, K. D. (2001). Bias, discrimination, and obesity. Obesity, 9(12), 788-805.

Puhl, R. M. i Heuer, C. A. (2009). The stigma of obesity: A review and update. Obesity, 17(5), 941-964. 
Puhl, R. M., Luedicke, J. i Grilo, C. M. (2014). Obesity bias in training: Attitudes, beliefs, and observations among advanced trainees in professional health disciplines. Obesity (Silver Spring), 22(4), 1008-1015.

Puhl, R. M., Schwartz, M. B. i Brownell, K. D. (2005). Impact of perceived consensus on stereotypes about obese people: A new approach for reducing bias. Health Psychology, 24(5), 517-525.

Rattazzi, A. M., Bobbio, A. i Canova, L. (2007). A short version of the Right-Wing Authoritarianism (RWA) Scale. Personality and Individual Differences, 43(5), 1223 1234.

Register, C. A. i Williams, D. R. (1990). Wage effects of obesity among young workers. Social Science Quarterly, 71, 130-141.

Robinson, E., Sutin, A. i Daly, M. (2017). Perceived weight discrimination mediates the prospective relation between obesity and depressive symptoms in US and UK adults. Health Psychology, 36(2), 112.

Roehling, M. V. (1999). Weight-based discrimination in employment: Psychological and legal aspects. Personnel Psychology, 52(4), 969-1016.

Rudman, L. A., Greenwald, A. G., Mellott, D. S. i Schwartz, J. L. K. (1999). Measuring the automatic components of prejudice: Flexibility and generality of the Implicit Association Test. Social Cognition, 17(4), 437-465.

Rudolph, C. W., Wells, C. L., Weller, M. D. i Baltes, B. B. (2009). A metaanalysis of empirical studies of weight-based bias in the workplace. Journal of Vocational Behavior, 74(1), 1-10.

Shi, L., Samuels, M. E., Richter, D. L., Stoskopf, C. H., Baker, S. L. i Sy, F. S. (1993). AIDSrelated knowledge and attitudes of social workers in South Carolina. Health \& Social Work, 18(4), 268-280.

Soto, L., Armendariz-Anguiano, A. L., Bacardí-Gascón, M. i Jiménez Cruz, A. (2014). Beliefs, attitudes and phobias among Mexican medical and psychology students towards people with obesity. Nutrición Hospitalaria, 30(1), 37-41.

Sutin, A. R., Stephan, Y. i Terracciano, A. (2015). Weight discrimination and risk of mortality. Psychological Science, 26(11), 1803-1811.

Sutin, A. R. i Terracciano, A. (2017). Perceived weight discrimination and high-risk healthrelated behaviors. Obesity, 25(7), 1183-1186.

Šverko, B. (1998). Vodič kroz zanimanja. Preuzeto s http://mrav.ffzg.hr/zanimanja/

Tiggemann, M. i Rothblum, E. D. (1988). Gender differences in social consequences of perceived overweight in the United States and Australia. Sex Roles, 18, 75-87.

Tiggemann, M. i Rothblum, E. D. (1997). Gender differences in internal beliefs about weight and negative attitudes toward self and others. Psychology of Women Quarterly, 21, 581593.

Urbanc, K. (2006). Izazovi socijalnog rada s pojedincem. Zagreb: Alinea. 
Whyte, J. (2010). Media portrayal of people who are obese. Virtual Mentor, 12(4), 320-323.

Zakrisson, I. (2005). Construction of a short version of the Right-Wing Authoritarianism (RWA) scale. Personality and Individual Differences, 39, 863-872.

\title{
Investigating the Explicit and Implicit Attitude towards Obese People among Students of Helping-Professions
}

\begin{abstract}
The aim of this study was to examine the explicit and implicit attitude towards obese people among students of two helping professions in Croatia. The study included 429 participants -students of psychology and social work at the University of Zagreb. The attitude was assessed using an experimental manipulation which consisted of a modified photograph (implicit measure), as well as the attitudes towards obese people scale (explicit measure). Negative attitude was found on both of the measures. There was a significant difference in the estimates of work performance and estimates of the three dimensions of personality depending on the body weight in the photograph. In comparison with the person of average weight, the obese person was estimated as less effective at work, more emotionally unstable, less extraverted and less open to experience. Psychology students were more stringent in assessing both the overweight and the average weight person. There was no significant interaction between body weight in the photograph and the study field of participants. On average, participants had a moderate level of explicit negative attitude against obese people. Also, results show a positive correlation between negative attitude and right-wing authoritarianism. There were significant, but low associations between implicit and explicit attitude measures, suggesting that there is a "hidden" aspect of the attitude that can be measured only implicitly. The results provide an insight into the under-researched understanding of attitude against obese among helping professions in Croatia and may provide useful guidelines for reducing negative attitude.
\end{abstract}

Keywords: attitude towards obese people, implicit measure of attitude, explicit measure of attitude, helping professions 


\title{
Investigación de la actitud explícita e implícita de los estudiantes de profesiones asistentes hacia los obesos
}

\begin{abstract}
Resumen
El objetivo de este trabajo fue investigar la actitud explícita e implícita de los estudiantes croatas de algunas profesiones asistentes hacia los obesos. En la investigación participaron 429 participantes, estudiantes de psicología y trabajo social en la Universidad de Zagreb. Se evaluó la actitud a través de la manipulación experimental de la fotografía de una persona con el peso variado (medida implícita) y a través del cuestionario (medida explícita). Se ha determinado la actitud negativa hacia los obesos tanto en la medida implícita como explícita. Se ha obtenido una diferencia significativa en la evaluación del rendimiento laboral y en la evaluación de tres dimensiones de personalidad basándose en el peso corporal de la persona en la fotografía. En comparación con las personas de peso promedio, los participantes para los obesos evaluaron menor rendimiento laboral, menor estabilidad emocional, menor extraversión y menor apertura a la experiencia. Aunque los estudiantes de psicología evaluaron más "estricto" las dos personas en comparación con los estudiantes de trabajo social, no se ha determinado la interacción entre el peso corporal en la fotografía y el tipo de estudio del participante. Se ha determinado también la relación entre la actitud negativa y el autoritarismo derechista. Las mediciones implícitas fueron significativamente, pero poco relacionadas con la explícita, lo que indica la existencia de una parte "escondida" de la actitud que está cubierta sólo por la medida implícita. Los resultados obtenidos muestran hallazgos que no están suficientemente investigados sobre la actitud de las profesiones asistentes en Croacia hacia los obesos y pueden ser directrices útiles para los programas de disminución de la actitud negativa.
\end{abstract}

Palabras clave: actitud hacia los obesos, medida implícita de la actitud, medida explícita de la actitud, profesiones asistentes

Primljeno: 10.11.2016. 